\title{
An Ongoing Debate: Are the Patients Receiving Angiotensin-Converting Enzyme Inhibitors and/or Angiotensin Receptor Blockers More Susceptible to COVID-19?
}

\author{
Süregelen Bir Tartıșma: Anjiotensin-Konverting Enzim \\ İnhibitörü ve/veya Anjiotensin Reseptör Blokörü \\ Kullanan Hastaların COVID-19’a Karșı Duyarlılığı Daha \\ Fazla midır?
}

\begin{abstract}
As a result of the unprecedented current pandemic, abundant publications about the various aspects of this disease appear in the scientific journals. Among them, one publication deserves special attention because of recommending a substantial change in the management of patients in the current pandemic. This publication recommended the disuse of angiotensin converting enzyme inhibitors and angiotensin receptor blockers because of the risk of worsening the infection. Immediately following its publication in the Lancet Respiratory Medicine, a vivid discussion emerged in the scientific communities. Herein we will try to summarize this event as a case and mention the important points of the discussion under the light of the relevant literature.
\end{abstract}

Keywords: Pandemic, Angiotensin, ACE, ACE2, Coronavirus, Covid-19

\section{Öz}

Halen içinde olduğumuz beklenmedik Covid-19 pandemisi ile ilgili bilimsel dergilerde konuya ilișkin çok sayıda makale yayımlandı. Bunlardan bir tanesi, halen tedavi görmekte olan hastaların tedavisinde önemli bir değișiklik önermesi nedeniyle özel olarak ele alınmayı hakketmektedir. Bu makalede, Anjiyotensin Konverting Enzim inhibitörleri ile Anjiotensin reseptör blokörü ilaçların hastanın durumunu kötüleștirme riski nedeniyle bırakılması önerilmekteydi. Makalenin Lancet Respiratory Medicine dergisinde yayımlanmasını takiben bilim çevrelerinde hararetli bir tartıșma bașladı. Burada bu olayı bir olgu șeklinde özetlemeye ve önemli noktaları ilgili bilimsel literatürün ıșığında değerlendirmeye çalıșacağız. Anahtar Sözcükler: Pandemi, Anjiotensin, ACE, ACE2, Coronavirus, Covid-19
Sarper Yilmaz', Nazif Elaldi², Hakan Ertin ${ }^{3}$

Department of Plastic Reconstructive and Aesthetic Surgery, Ufuk University School of Medicine, Ankara, Turkey

2 Cumhuriyet University Faculty of Medicine, Department of Infectious Diseases, Sivas, Turkey

${ }^{3}$ Istanbul University Istanbul University School of Medicine, Department of History of Medicine and Ethics, Isanbul, Turkey.

Received/Gelis : 07.04.2020 Accepted Kabul: 08.04.2020

DOI: 10.21673/anadoluklin.716125

Corresponding author/Yazıșma yazar Sarper Yilmaz

Dikmen Caddesi, 176/7 Cankaya, 06530

Ankara, Turkey

E-mail: sarper@bilkent.edu.tr

\section{ORCID}

Sarper Yilmaz: 0000-0002-3078-2264 Nazif Elaldi: 0000-0002-9515-770X Hakan Ertin: 0000-0002-8193-5865 


\section{OVERVIEW}

An unprecedented pandemic continues its burst nowadays. As a result, abundant publications about the various aspects of this disease appear in the scientific journals. Among them, one publication deserves special attention because of recommending a disputable change in the management of patients in the current pandemic. This publication was by Fang et al., and it appeared on $11^{\text {th }}$ of March in Lancet Respiratory Medicine (1). This was a short correspondence suggesting the disuse of angiotensin-converting enzyme inhibitors (ACEi) and angiotensin receptor blockers (ARBs) because of the risk of worsening the infection. The article which has been published in the Lancet Respiratory Medicine thereafter aroused a considerable echo both in the lay press and a number of scientific communities. In spite of the emerging confusion on this issue, some scientific associations quite rapid to react and declared decisive statements. However, scientific journals are not so swift to publish the correspondences. Our aim is to summarize this vivid discussion around the aforementioned article of Fang et al.

\section{THE CASE}

Briefly, Fang et al. stated that the use of ACEi and ARBs leads to the high expression of ACE2 (angiotensin-converting enzyme 2) which was also known as a cell membrane receptor favorable for the entry of Covid-19. As a result, they claimed that the high expression of ACE2 would lead to an accelerated entry of viral particles into the cells further worsening the clinical outcome of the patients. For this reason, they recommended the cessation of this group of hypertensives. Additionally, they stated that thiazolidinediones and ibuprofen can also increase the expression of ACE2 (1). However, before that, it would be useful to bring on a previous letter published on March $3^{\text {rd }}$ which mentions exactly the same claim with Fang et al. (2). In their correspondence, Sommerstein and Grani pointed out the possible risk of using ACEi and ARBs because of the connection between ACE2 receptors and Coronaviruses. In fact, this was also a short communication in the form of a rapid response to an article titled "Prevent a Covid-19 Epidemic" which was published in British Medical Journal. Following a fortnight, a comprehensive reply to this publication by Kuster et al. appeared on $18^{\text {th }}$ of March in another journal (3). The authors stated that the notion put forward by Sommerstein and Grani has been quickly picked up by the lay press and sparked concerns among physicians and patients regarding the intake of renin-angiotensin system inhibitors. Nevertheless, quite rightfully, they emphasized the fact that there is no data proving a causal relationship between ACE2 activity and Covid-19 associated mortality. They mentioned that an assumption of a causal relationship between ACEi or ARBs intake and deleterious outcome in Covid-19 was not legitimate. Finally, the authors firmly opposed the recommendation of disuse of these drugs in the treatment of Covid-19 infected patients with cardiovascular problems. We want to mention the peculiarity of the publishing procedure of these two articles. The first one was published as a rapid response to a general article about the epidemic probably without any peer review (just three days later). However, the opposing article had to go over a revision process in another journal. They sent the reply to the journal on $11^{\text {th }}$ of March and after a revision process online appearance of it was on $18^{\text {th }}$ of March. The issue deserves attention because of the fact that it is relatively easy to write something which interferes directly with the treatment of patients in the form of rapid or brief communication but it is not that easy to write something against it, no matter how the initial one is irrelevant or groundless.

A similar incident happened in the distinguished Lancet Journal. Fang et al. has made another serious statement about the potential harm of ACEi, ARBs, thiazolidines, and ibuprofen in patients with SARSCoV-2 infections (1). Although their publication appeared 8 days after Sommerstein and Grani's article, they were unaware of this article. Because Fang et al. put forward a number of pretentious suggestions, it would be better to handle them one by one.

First claim: The letter began by quoting three most recent cohort studies (published on March 24, $28,29)$, mentioning the comorbidities (hypertension and diabetes mellitus) of COVID-19 patients. 
It was noted that these patients were frequently treated with ACEi, without giving any details. After pointing out the importance of human pathogenic coronavirus' binding to their target cells via ACE2 receptors, the authors claimed that ACE2 expression is substantially increased in diabetic patients treated with ACEi and angiotensin receptor blockers (ARBs). Let's see what they actually wrote: “The expression of ACE2 is substantially increased in patients with type 1 or type 2 diabetes, who are treated with ACE inhibitors and angiotensin II type-I receptor blockers (ARBs)". For this statement, their reference was an article of Wan et al. (4). However, there was nothing about this issue in Wan et al's article. This article deals with the similarities between the spike protein receptor binding domains of SARS-CoV and $2019 \mathrm{nCoV}$. Pertaining to these similarities, Wan et al. suggested that ACE2 receptors on the epithelial cells were important binding sites for the $2019 \mathrm{nCoV}$ like the original SARS-CoV. It should be emphasized that this is just a hypothesis which has to be corroborated. In fact, one may well think that the similarity between two receptors are not that strong, being $73-76 \%$ in receptor binding domain and only $50-53 \%$ in more specific receptor binding motif. Indeed, there are many objections on the critical role of ACE2 receptors in the Coronavirus infection and transmission $(5,6)$.

Second claim: Fang et al. asserted that the treatment with ACEi and ARBs (angiotensin II type-I receptor blockers) would result in an upregulation of ACE2 in the hypertensive patients. For this claim, they provide a reference to an article by Li et al. (7). Contrary to their suggestion, however, that article is quite straightforward in emphasizing that "the activity and the action of ACE2 are not affected by the ACEI, further distinguishing ACE2 from the classical ACE." In fact, this information has been well known since the first discovery of ACE2, identified in the year 2000 simultaneously by two independent research teams, both revealing that ACE2 was not affected by the ACEi due to its biochemically and pharmacologically distinct features $(8,9)$. During literature review we detected an experimental rat study revealing an increased expression of ACE2 in cardiac tissues under ACEi and /or ARBs, however
Fang et al. did not refer to this article which would a bit strengthen their claim (10). There are also some reports dealing with the increased expression of ACE2 in patients with hypertension. In a relatively recent study, significant elevations of ACE2 was shown in men with uncontrolled Essential Hypertension in comparison with another group treated with ACE inhibitors (11). According to this clinical study, the increase in the expression of ACE2 in hypertensive patients was due to the severity of hypertension and in patients receiving ACEi, this increase was not detected. The authors also pointed out the possible effects of ACE I/D polymorphism interfering indirectly with ACE2 expression. In another clinical study, it was shown that ACE2 expression was significantly higher in the smokers compared to the non-smokers (12). It is obvious that the differences of ACE2 expression is the result of a number of variables that should be further investigated. It is hard to understand the reasoning of Fang et al., directly accusing $\mathrm{ACEi}$ and $\mathrm{ARBs}$ for the increase in ACE2 expression.

Third Claim: Authors stated that "ACE2 can also be increased by thiazolidinediones and ibuprofen". We that this was oddest claim. They did not provide a reference for this claim, moreover they did not mention anything in their article relating to these drugs. It seems that there was only one paper in the literature reporting an increased expression of ACE2 in response to ibuprofen and this was done in rats and ACE2 expression was studied in cardiac tissues (13). However, urged with this publication, the French Health Minister Olivier Veran warned the public about the risk of worsening of Covid-19 infections due to ibuprofen intake. Even an official from WHO (Christian Lindmeier) offered caution about the use of ibuprofen in these patients (14).

\section{OUR INTERPRETATION}

There is an interesting way of reasoning about the increased expression of ACE2 and a readily virus entry to the cell through this receptor. It is generally believed that increased ACE2 expression should directly result in an increased delivery of the virus particles into the cell. According to the popular 
speculation, ACEi lead in a decrease in angiotensin II, leaving the ACE2 receptors available for coronavirus access. However, the same ACEi lead to an increase in angiotensin I and it is well known that it is a substrate for ACE2 as well. As a result of angiotensin I - ACE2 interaction, angiotensin 1-9 is produced. The information about the functional aspects of this product is scarce. While it was initially thought to be merely as an intermediate step in the conversion of angiotensin I to angiotensin II, recent evidence showed that it has significant cardiovascular bioactivity (15). Additionally, a number of other active agents like apelin-13, dynorphin A 1-13, desArg9-bradykinin, neurotensin 1-13 and kinetensin were also metabolized by ACE2 (16). Therefore, it does not make much sense to claim that ACE2 receptors would become free under the influence of ACEi drugs. Inversely, increased angiotensin I levels may boost the need for additional ACE2, may well be triggering an upregulation of ACE2. Of course, these are exclusively theoretical issues, however interpretations should be deepened to the molecular level before exclaiming big clinical assertions. Still, that also will not be suffice for deducing a tangible conclusion without clinical data. Another noteworthy remark of Fang et la. was their suggestion of using calcium channel blockers instead of ACEi, on the ground that they could not find any evidence about a relationship between calcium channel blockers and ACE2. This was also unacceptable. Even if the warnings of Fang et al. would have been rational about ACEi, their suggestion of another antihypertensive drug on the ground of an ordinary literature review would be neither reasonable nor ethical. Unfortunately, the Lancet Respiratory Medicine editorial overlooked all these points.

\section{Reactions to the publication}

Following the publication of the article of Fang et al., a number of objections began to appear in the scientific communities. On March 13, European Society of Cardiology issued a statement against these claims (17): “The Council on Hypertension of the European Society of Cardiology wish to highlight the lack of any evidence supporting harmful effect of ACE-I and ARB in the context of the pandemic COVID-19 outbreak. The Council on Hyper- tension strongly recommend that physicians and patients should continue treatment with their usual anti-hypertensive therapy because there is no clinical or scientific evidence to suggest that treatment with ACEi or ARBs should be discontinued because of the Covid-19 infection" On March 17, American College of Cardiology, American Heart Association and Heart Failure Society of America announced a joint statement about this issue and they firmly recommended patients taking $\mathrm{ACEi}$, ARBs who contract Covid-19 should continue treatment (18). They also reminded the lack of clinical studies for justifying such a theoretical assertion. In fact, these two examples are only a small portion of the reactions held by a number of scientific associations. For these reactions and a most recent review of this case, one can easily search NephJC website (19).

Nevertheless, until very recently, one can hardly find a comprehensive reply to the claims of Fang et al. in the scientific journals apart from Kustler et al.s article (3). It is obvious that article of Fang et al. has been compiled in a quite hastily manner. They did not review the recent literature carefully, and obviously they were unaware of Sommerstein and Grani's previous letter mentioning the same views. Moreover, their statement was obviously irrelevant with the references they provide. As a result of this, they made an apparently flawed hypothesis which may negatively interfere with the management of the current patients. It seems that the editors of Lancet Respiratory Medicine did not review the correspondence properly which contains bold recommendations directly related to the ongoing treatments in the current pandemic. We have sent a letter as a reply to the article of Fang et al. on March 21 and described the inconsistencies in brief. On $24^{\text {th }}$ of March I received a rejection letter:

"At the present time, there is fierce competition for space in the journal, and we are trying to avoid publishing content that overlaps with current articles we have in the pipeline. We encourage articles that expand on current knowledge and consider future debates or discussions. After assessing your piece, we feel that we cannot prioritise it for publication"

Following the publication of the article on 11th of March, amidst a vivid reaction within the scien- 
tific community, almost nothing appeared on Lancet Respiratory Medicine against these claims until $26^{\text {th }}$ of March. On this date, along with the reply of the authors, three letters against the views of Fang et al. appeared $(20,21,22)$. Apparently, the editors preferred to wait the reply of Fang et al. before publishing these letters and they further retarded the appearance of the opposing views. When we examined these responses, we that none of the responders noticed the irrelevancies of the references provided by the authors. Moreover, none of them noticed that this issue was claimed previously and a comprehensive reply to this claim was provided by Kuster et al. on March 18. In fact, even before Kuster et al., a number of short responses to Sommerstein and Grani in British Medical Journal. As early as the $10^{\text {th }}$ of March Amatruda O., warned about the unwarranted panic created by Sommerstein's letter and reminded the positive effects of ACEi and ARBs in elderly patients with viral pneumonia (23). Neither the responders to Fang's letter nor the Lancet editors carefully reviewed the literature on this issue and apparently overlooked some of the crucial details. It seems that British Medical Journal was quite open to the responses against the letter of Sommerstein and Grani. Even a number of very short responses, in a commendable manner, swiftly have found space on the online journal.

\section{CONCLUSION}

In our opinion at the end of this pandemic as health care professionals we would have learned a lot about our shortcomings and accomplishments as well. Surefire, meticulous evaluations will be performed on various aspects of this pandemic. We wanted to point out two critical issues herein. The first point is about the publishing policies of some "high impact factor" journals. Although a journal cannot be held accountable because of the views of their authors, it is for sure that they should have some responsibilities for the scientific communities and the readers. That is the mainstay of the peer review process. The editors should have the capability of discriminating the accuracy and the appropriateness of the messages conveyed in the articles. It is not defensible to spend a couple of weeks for the review of an experimental rat study, while publishing a letter conveying unsafe critical recommendations just in one day. We think that these issues should be widely discussed in an openhearted manner. The second point is the problem of interference of highly theoretical issues directly into the clinical practice. Keeping in mind that our information on the molecular dynamics of the various pathologic processes (even physiologic ones) are still insufficient, we have to refrain from making fierce and hasty deductions which may comprise hazardous potentials for the established treatment modalities. These kinds of recommendations should only be done with sound judgement and only after meticulous literature research.

\section{REFERENCES}

1. Fang L, Karakiulakis G, Roth M. "Are patients with hypertension and diabetes mellitus at increased risk for COVID-19 infection?" Lancet Respir Med; published online March 11. https://doi.org/10.1016/S22132600(20)30116-8.

2. Sommerstein R, Grani C, "Re: Preventing a Covid Pandemic: ACE inhibitors as a potential risk factor for fatal Covid-19”, British Medical Journal, 368, 2020, March 3. https://www.bmj.com/content/368/bmj.m810/rr-2

3. Kuster GM, Pfister O, Burkard T, "SARS-CoV2: Should inhibitors of the renin-angiotensin system be withdrawn in patients with Covid-19?", European Heart Journal, 2020, March 18. doi:10.1093/eurheartj/ehaa235.

4. Wan Y, Shang J, Graham R, et al. Receptor recognition by novel coronavirus from Wuan: An analysis based on Decade-Long Structural Studies of SARS. J Virol, 2020;94(7). pii: e00127-20. doi: 10.1128/JVI.00127-20.

5. Procko E, "The Sequence of Human ACE2 is Suboptimal for Binding the S Spike Protein of SARS coronavirus 2", BioRxiv, March 17, 2020.

6. Cao Y, Li L, Feng Z et al., "Comparative genetic analysis of the novel coronavirus (2019-nCoV/SARS-CoV-2) receptor ACE2 in different populations", Cell Discovery, 6:11, 2020.

7. Li XC, Zhang J, Zhuo JL, "The vasoprotective axes of the renin-angiotensin system: physiological relevance and therapeutic implications in cardiovascular, hypertensive and kidney diseases", Pharmacological Research, 125(Pt A): 21-38, 2017.

8. Donoghue $\mathrm{M}$, Hsieh $\mathrm{F}$ et al., "A Novel Angiotensin- 
Converting Enzyme-Related Carboxypeptidase (ACE2) Converts Angiotensin I to Angiotensin 1-9", Circulation Research, 87:e1-e9, 2000.

9. Tipnis SR, Hooper NM et al., "A Human Homolog of Angiotensin-Converting Enzyme", The Journal of Biological Chemistry, 275(43):33238-33243, 2000.

10. Ferrario MC, Jessup J, Chappell MC et al., "Effect of Angiotensin-Converting Enzyme Inhibiton and Angiotensin II Receptor blockers on Cardiac Angiotensin-Converting Enzyme-II ”, Circulation, 111:2605-2610, 2005.

11. Hristova M, Stanilova S, Miteva L, "Serum concentration of renin-angiotensin system components in association with ACE I/D polymorphism among hypertensive subjects in response to ACE inhibitor therapy", Clinical and Experimental Hypertension, 41(7):662-669, 2019.

12. Cai, G. Bulk and Single-Cell Transcriptomics Identify Tobacco-Use Disparity in Lung Gene Expression of ACE2, the Receptor of 2019-nCov. Preprints 2020, 2020020051 (doi: 10.20944/preprints202002.0051.v2).

13. Qiao W, Wang C, Chen B, "Ibuprofen attenuates cardiac fibrosis in Streptozotocin-induced dibaetic rats", Cardiology, 131(2):97-106, 2005.

14. https://www.sciencealert.com/who-recommendsto-avoid-taking-ibuprofen-for-covid-19-symptoms, reached on March 20, 2020.

15. Flores-Sotomoyor, Rivera-Mejias P, Vasquez-Trincado C et al. "Angiotensin-(1-9) prevents cardiomyocyte hypertrophy by controlling mitochondrial dynamics via miR129-3p/PKIA pathway", Cell Death \& Differentiation, March 9, 2020, doi: 10.1038/s41418-020-0522-3.

16. Vickers C, Hales P, Kaushik V, "Hydrolysis of Biological Peptides by Human Angiotensin Converting Enyzme Related Carboxypeptidase (ACE2)", J. Biol. Chem., 227(17):14838-43, 2002
17. https://www.escardio.org/Councils/Council-on-Hypertension-(CHT)/News/position statement-of-the-esccouncil-on-hypertension-on-ace-inhibitors-and-ang, reached on March 29, 2020.

18. https://www.acc.org/latest-in-cardiology/articles/2020/03/17/08/59/hfsa-acc-aha-statement-addresses-concerns-re-using-raas-antagonists-in-covid-19, reached on March 29, 2020.

19. Sparks MA, Hiremath S et al. "The Coronavirus Conundrum: ACE2 and Hypertension Edition” NephJC, http:// www.nephjc.com/news/covidace2, reached on March 29,2020

20. Braun JD, "Antihypertensive drugs and risk of Covid-19?", Lancet Respiratory Medicine, March 26, 2020, https://doi.org/10.1016/ S2213-2600(20)30158-2, reached on March 30, 2020.

21. Tignanelli CJ, Ingraham NE, Sparks MA et al, "Antihypertensive Drugs and risk of Covid-19?", Lancet Respiratory Medicine, March 26, 2020, https://doi.org/10.1016/ S2213-2600(20)30153-3, reached on March 30, 2020.

22. Lo KB, McCullough PA, Rangaswami J, "Antihypertensive Drugs and risk of Covid-19?", Lancet Respiratory Medicine, March 26, 2020, https://doi.org/10.1016/ S2213-2600(20)30156-9, reached on March 30, 2020.

23. Amatruda O., "ACE inhibitors and ARBs are not a risk factor for fatal for Covid-19 Re: Preventing a Covid-19 pandemic", BMJ, 2020, 368:m810; https://www.bmj. com/content/368/bmj.m810/rr-16, reached on April 6, 2020 . 